\title{
Geography Matters More: Geographical and Institutional Determinants of Income in Brazilian States*
}

\author{
Fernanda Llussa ${ }^{\dagger}$
}

September 5, 2007

\begin{abstract}
Brazil displays a geographic and institutional diversity unique in the world. It extends in a north-south direction rather than the east-west of other countries of similar size. Given the current debate on the relative role of geography and institutions in determining income levels, Brazil provides a single testing ground for the direct and indirect effects of geography. This paper evaluates how much of the income differences across Brazilian regions and states stem from geographic characteristics and institutional characteristics, the latter in turn partly determined by geography. Our results show, first, that the rate of convergence of state income per capita increases substantially once regional effects are taken into account. Second, institutions, when instrumented with regional dummies, are a significant determinant of state income levels. However, when we add additional geographic characteristics, some institutions cease to significantly affect income. The message from Brazilian data seems to be that, tough geography and institutions matter for income, geography matters more.
\end{abstract}

Keywords: Economic Growth; Geography; Institutions.

JEL Codes: O11; O18; O43

\footnotetext{
${ }^{*}$ We thank John Gallup, Key Hirano, Ekaterini Kyriazidou, Luisa Lambertini, Carlos A. Végh and Kenneth L. Sokoloff for helpfull discussions and comments. We also thank participants at seminars at Universtity of California, Los Angeles and Universidade Nova de Lisboa. The author is responsible for all errors and omissions.

${ }^{\dagger}$ Faculdade de Ciências e Tecnologia, Universidade Nova de Lisboa and INOVA Research Center.
} 


\section{Introduction}

Brazil is the fifth largest country in the world, occupying half of the South American land area and a larger area than the continental United States. Most importantly, Brazil's land mass extends in a north-south direction rather than the east-west of most countries of similar size, including Russia, Canada, China and the United States ${ }^{1}$. Spanning from north of the Equator to the south of the Tropic of Capricorn, Brazil displays an exceptional geographic diversity, thus providing a unique testing ground for the study of the relation between geography, economic growth and income levels.

Geographical characteristics - such as temperate weather, access to the sea and incidence of tropical diseases - can indeed affect growth and income levels. Gallup, Sachs and Mellinger (1998) have put forward the thesis that geography impacts growth directly and, after controlling for economic policies and institutions, found that location and climate affect growth and income through transport costs, disease burdens and agricultural productivity. ${ }^{2}$ Other authors, such as Diamond (1997) and Jones and Hall (1998) have linked geography and economic development through summary indicators such as distance to the tropics. While Diamond relates the historical development of Europe with the availability of resources specific to temperate climates, Jones and Hall (1998) have estimated that the distance to the tropics explains around one third of crosscountry differences in the level of per capita GDP.

Geography can also impact growth indirectly through institutions: regions with less favorable geographic characteristics tend to end up with worse institutions. Acemoglu et al. (2000) uses mortality rates in the eighteen century as an instrument for the quality of institutions today. According to Acemoglu, the type of institutions set up by European colonizers varied according to the physical conditions encountered in former colonies such that places with more adverse conditions led to the emergence of "extractive" institutions which, persisting in time, have led to lower rates of economic growth. The authors estimate the effects of institutions on income per capita and find that differences in institutions explain about three quarters of the income differences across former colonies. Moreover, once the effect through institutions is accounted for, geographical characteristics - notably the distance to the Equator - do not affect income. ${ }^{3}$ In a similar vein, Engerman and Sokoloff (1997) point out that factor endowments such as climate and soil explain why the social infrastructure of the United States and Canada was more conducive to long run economic success

\footnotetext{
${ }^{1}$ That is., the four largest countries in terms of area.

${ }^{2}$ Gallup et al. (1998) also find that geography affects policy choices indirectly through economic policies: more adverse geographical characteristics associate with policies that are less conducive to economic growth.

${ }^{3}$ Acemoglu et al. (2001) find that that European colonies that were relatively rich in 1500 have experienced a "reversal of fortune" inconsistent with a direct effect of geography on growth. The authors claim, instead, that European colonization dramatically altered local institutions given that Europeans were more likely to set up investment-enhancing institutions in areas that were relatively poor and "extractive" institutions in areas that were relatively rich, namely in terms of natural resources.
} 
than the social infrastructure of Latin American countries. Rodrik, Subramanian and Trebbi (2002) estimate the joint contribution of institutions, geography and trade to income levels and find that the quality of institutions is the single and dominating factor accounting for differences in income per capita. Geographical characteristics play a weak direct role once institutions are accounted for, but have a strong indirect role through their impact on the quality of institutions. As a response, McArthur and Sachs (2001) show, for a wider sample, that both institutions and geographically-related variables - malaria incidence, life expectancy at birth - are closely connected to per capita GDP. ${ }^{4}$

We claim that Brazil's uniquely diverse geography and regional institutions turn it into a key testing ground for the relative worth of the direct and indirect effect views on the impact of geography on development. The five administrative regions in Brazil differ widely in terms of geographic characteristics: the North, Northeast and Center-West, located in the tropics, constitute the least developed part of the country; the Southeast and the South, have been the most developed since at least the mid-1800's. As Roett (1978) states, Brazil can be characterized as a "federation of economically unequal partners".

Thus, the aim of this work is to study how much of the differences in growth and income among Brazilian regions can be explained directly by geography, or indirectly, through the impact of geography on institutions. The data set used in this study includes a wide number of economic, geographic and institutional data organized by Brazilian state for the period from 1940 to 1995, from the Anuário Estatístico do Brasil and other sources, directly collected by the author. These data can be provided by the author upon request.

This paper is organized as following: in section 2, we characterize Brazilian regions in terms of historical, geographical and social characteristics; in section 3 , we briefly discuss convergence of state's income per capita focusing on the period 1940-1995 and in section 4, we use panel data from 1950 to 1995 to quantify how much geography is relevant either directly or indirectly to explain differences in cross-state per capita income.

The addition of regional dummies increases the speed of convergence in growth rates across states, suggesting that convergence in Brazil is stronger among states that share some basic geographic characteristics. The main conclusion is that geography alone can explain a substantial fraction of income differences across states. When regional dummies are used as instruments for institutions in a two stage least square panel regression we observe that institutions are significant in explaining states's income per capita. However, once other geographical characteristics are added to the specification, institutions generally become irrelevant while geographical variables are significant.

\footnotetext{
${ }^{4}$ Sachs (2003) shows that the rate of malaria transmission, which is highly correlated with geographical and ecological characteristics, affects per capita income directly, even after controlling for the role of institutions.
} 


\section{Characterizing Brazilian Regions}

\subsection{Historical Background}

The first region to be settled in the United States was the Northeast, still one of the most dynamic and developed in the country today. On the contrary, the Northeast region of Brazil, tough the first occupied by Portugal and the most developed until the mid-nineteenth century, was surpassed by the regions of southern Brazil never to regain preeminence. ${ }^{5}$ So, if history matters in some countries, in Brazil it seems that geography (or institutions) matter more.

The Northeast-Southeast economic divide stems from changes in the nineteenth century Brazilian economy and society. As Leff (1982) points out, until the Second World War the dynamic impulse of the Brazilian economy derived from exports: regions endowed with exhaustible natural resources in high demand abroad were settled and economically explored; as external demand declined or resources were exhausted, economic development came to a halt. Development occurred through successive cycles associated with primary resources: the sugar and cotton of the Northeast (1539 to 1650); mining in Minas Gerais, Mato Grosso and Goiás (1690 to 1760); coffee in Paraná, São Paulo and Rio de Janeiro (1810-1860); rubber in the Amazon (1869-1912 and 19421945). The Northeast, Brazil's richest and most populated region, slowly lost its economic significance as a result of the poor performance of sugar and cotton exports in the 19th century.

The development of coffee production and exports in the Southeast impacted the Northeast's economy negatively. Coffee exports led to exchange rate appreciation, harming sugar exports by the Northeast in a Dutch-disease type of effect. Besides, the rise in Brazilian coffee exports led Cuba to switch to sugar, harming Northeast's staple export. Industrialization and urbanization became closely associated with export growth in the south and southeast. ${ }^{6}$

In nineteenth century Brazil, slaves were a major forms of capital formation. Slave imports from Africa suggest the geographic shift in regional economic fortunes: between 1821 and 1843 the Southeast imported 73 percent of the slaves arriving in Brazil while the Northeast still had the larger share of Brazil's stock of slave-labor force. In spite of the interruption of slave imports in 1852, between 1852 and 1888, southern planters bought a sizable fraction of the Northeast's slave labor. The greater productivity of the Southeast made it possible for planters in the region to offer higher prices for slaves, and cover the high cost of transporting them from the Northeast. By the time slavery was abolished, approximately 75 percent of the country' slave population was concentrated in

\footnotetext{
${ }^{5}$ This is consistent with the thesis in Acemoglu et al. (2001) that European colonies that were relatively rich in 1500 experienced a "reversal of fortune".

${ }^{6}$ Between 1841 to 1850 the Northeast, though containing 48 percent of Brazil's population as compared to 49 percent in the South, was growing at rates of - 0.6 percent as compared to 2 percent in the South and 6.2 in the Amazon. Even population growth, at 1.2 percent, was lower than the 2.5 percent of the South. See Furtado (1995). Estimates in Leff (1978, p. 31) suggest that between 1822 and 1913 the real per capita income of the Northeast fell by aproximately $30 \%$.
} 
the Southeast.

When the large-scale flow of European immigrants to Brazil began in the end of the nineteenth century, the Southeast region was already firmly established as the most dynamic one. Higher levels of income per capita were associated with economic opportunities that attracted substantial masses of southern Europeans. Brazilian society became substantially more diverse ethnically and culturally.

\subsection{Geography}

According to the state's administrative division in the 1990's, the Northeast region is composed of nine states - Maranhão, Piauí, Ceará, Rio Grande do Norte, Paraíba, Pernambuco, Sergipe, Alagoas and Bahia - the North by seven states - Amazonas, Pará, Roraima, Rondônia, Acre, Amapá and Tocantins - the Southeast by four - São Paulo, Rio de Janeiro, Espírito Santo and Minas Gerais - and the South by three - Paraná, Santa Catarina and Rio Grande do Sul. The Center-West region was made up of only two states in 1950, Mato Grosso and Goiás and has added one more state since then, Mato Grosso do Sul .

Brazilian income is highly concentrated. Between 1950 and 1995, the Southeast region alone has been responsible for about 60 percent of Brazil's GDP. It is the most industrialized, with $4.8 \%, 20 \%$ and $32.2 \%$ of Brazilian agricultural, service and product GDP in 1995. The numbers for the richest state, São Paulo, are $2.5 \%, 13.2 \%$ and $18.4 \%$, while the poorest state, Piauí, is responsible for only $0.1 \%, 0.1 \%$ and $0.3 \%$ of Brazilian sectorial GDP. After the Southeast, the second most important region is the South, followed by the Northeast, Center-West and finally, the North region.

In terms of land area, the Northeast region occupies almost half of Brazil (42\%), followed by the Center-West (22.1\%), the Northeast (18.3\%), the Southeast $(10.8 \%)$ and, finally, the South $(6.8 \%)$ as shown in Table 1.

Brazil has eleven different ecozones ranging from temperate to tropical: $33.9 \%$ of the land area is in tropical ecozones and $4.8 \%$ in temperate ecozones, the rest being situated in the subtropical ecozone. The poorest regions of the country - the North and Northeast - have more than 30\% of their land area in the tropical ecozone, which makes up at most $0.2 \%$ of the South and Southeast. As to dry ecozones, they cover a large part of the least developed regions - $61.8 \%$ and $40.8 \%$ of the Northeast and Center-West, respectively - and only around 1 $\%$ of the South and Southeast (see Table 1).

River transportation has not played an important role in Brazil's development since virtually all of rivers run parallel to the coast, the exception being the Amazon. Neither the Amazon nor the other rivers are navigable throughout, because they run into falls and rapids in the Great Escarpment, a steep facade along the coast 2,000 to 2,600 feet high which makes access to the interior difficult. ${ }^{7}$

\footnotetext{
${ }^{7}$ Baer (1989) cites the Great Escarpment as a major reason for the slow development of the interior regions before the twentieth century.
} 
In terms of coastal population, in 1995, about $30 \%$ of the population lived within 100 kilometer from the coast, in an area which corresponds to less than $10 \%$ of the country's total area. Table 1 shows the percentage of coastal population in each region.

Malaria is the most important tropical disease in terms of number of cases in Brazil. ${ }^{8}$ Malaria does not necessary kill the infected person but limits his or her work capacity. Workers become less productive, compromising growth. Besides, resources must be allocated to combat the disease. In spite of improved living conditions, the regional share of population residing in the malaria area did not change significantly between 1965 and 1990.: from $42 \%$ in 1965 to $38 \%$ in 1990. Table 1 shows the percentage of malaric population in each region.

Brazil is a resource abundant country, specially as far as minerals, but mineral production is only around $4 \%$ of current Gross Domestic Product, a small figure when compared with similarly endowed countries such as Australia (15\%) and Canada (8.5\%). ${ }^{9}$ It is important to point out that mineral production is a relatively expensive activity which may explain why richer nations produce relatively more. In the case of Brazil, the yearly mineral production corresponds to only about $1 \%$ of the 48 billion tons estimated total reserves in 1990.

Brazil is not self-sufficient in oil: in 1995, Brazil produced 40.6 million tons and imported 29.3 million tons. Brazil's oil reserves are around 2.5 billion barrels, diminute when compared with the 362 billion barrels of the MiddleEast. Table 1 shows regional mineral production as a percentage of region's GDP and regional oil production in 1000 liters.

\subsection{Institutions}

The 1991 Brazilian census estimated the population at 147 million. This makes Brazil the sixth most populous nation in the world, after China, India, the United States, Indonesia and Russia. As Table 2 shows, the population is mainly concentrated in the Southeast and the Northeast, which together account for 70 percent of the country's population. Given the country's considerable area, population density is relatively low, standing at about 18.2 persons per square kilometer in 1995 . However, density varies extraordinarily among states and regions, from 2.9 per square kilometer in the North region to 71.3 in the Southeast region and 135 in São Paulo state.

The distribution between rural and urban population has changed substantially from the 1940 's, when all regions had more than half of their population

\footnotetext{
${ }^{8}$ In 1993, positive blood samples for malaria were about 483,367 compared to 274,084 of schistosomiais mansoni and 51,325 cases of cholera, the other two most important tropical diseases in terms of incidence. The less developed regions are the ones at greater risk of tropical disease. They also lack in terms of capacity to diagonose and treat these illness which means that these numbers are only an approximation and probably much lower than they should be. The interaction of disease and climatic conditions needs to be disentangled to understand income differences across Brazil.

${ }^{9}$ Excluding energy producing minerals - oil, mineral coal and natural gas - the GDP share of mineral production falls to $1.6 \%$.
} 
classified as rural, to 1995, when the national share of rural population decreased to $22 \%$. The South has the lowest share of rural population, around 10 percent, and together with the Southeast and Center-West has experienced a major sectorial shift since 1940. Table 2 shows regional rural population in 1940 and 1995 as a percentage of regional population.

Brazil is a latecomer to educational development, in spite of the profound changes in the last five decades, as the share of the country's literate population doubled, from $23 \%$ to $64 \%$ in the 1940-1991 period. The South has had the highest literacy rate of the country in the whole period, $51 \%$ in 1940 and almost $88 \%$ in 1995, a more than 20 percent difference to the Northeast. In terms of female literacy, the differences between regions are much less pronounced, with all the regions within a 5 percent range of each other. The substantial migration of low-skilled workers from the Northeast to the Southeast may be responsible for the smaller literacy rate of the most developed region of the country.

Life expectancy at birth in Brazil was 42.7 years in 1940, increasing to 65.8 years in 1991, with no major differences across regions. Life expectancy in years and the level of GDP per capita are highly correlated, with a simple correlation coefficient of $69.5 \%$ for the 24 Brazilian states in the period 1940-1991. The rates of infant mortality, on the other hand, exhibit in full force the diversity of Brazil, with the South, Southeast and Center-West rates about a third of infant mortality in the Northeast. The South and Southeast are also the states with lowest fertility rates - about half the level of the poorest states - and the highest share of population above 65 years of age.

Brazil has the largest share of people of African descent, with the exception of Nigeria. Slavery was abolished in Brazil in 1888 and miscegenation has been widespread, explaining the decrease of the share of whites in Brazil's total population. ${ }^{10}$ In the North, for instance, the high rate of miscegenation between 1950 to 1995 led to a decrease in the share of whites dropped from $31 \%$ to $20 \%$, but the decrease in the percentage of whites has occurred in all regions, tough less pronounced in the South. as to the levels, the share of whites in the population increases from north to south, with a difference as large as 84 and 20.

As regards political institutions, the level of party competition is highest in the Southand Center-West, but political alienation has increased in all regions.

At the bottom of Table 2 we present the income per capita levels of the different regions, their share of total Brazilian GDP and the sectorial breakdown of regional product. Again the Southeast has the lowest share of its GDP in agriculture, as well as the highest share in services. In sum, the picture of substantial regional asymmetry, both in income per capita and institutions.

\footnotetext{
${ }^{10}$ As Brown (1997) put it, "Historically, Brazilian social, cultural and political structures suppressed the issues of racism and racial inequality. Therefore, black political mobilization was also repressed, and barriers were created to prevent the development of strategies and policies to prevent and address the consequences of racial discrimination"
} 


\section{Geography and Convergence}

The recent growth literature has focused on regional income convergence using the neoclassical growth model framework, after Barro and Sala-i-Martin (1991 and 1995) failed to find evidence of unrestricted convergence for a wide crosssection of countries. However, these authors have uncovered evidence of unrestricted convergence among US states between 1880 and 1987, as well as among 73 regions of Western Europe from 1950 to 1985 and Japanese prefectures in the 1930-1990 period. Ben-David (1993), who studied convergence among regions and countries of the European Community also obtained statistically significant results in favor of unrestricted convergence.

As to developing countries, the results are more mixed. While Jian, Sachs and Warner (1994) did not find unrestricted convergence in their study of Chinese regions between 1952 and 1993, as well as mixed evidence on the dispersion of the logarithm of income per capita. In their study of India, Bajpai and Sachs (1996) found evidence of unrestricted convergence for Indian states between1961 and 1993, confirmed by Cashin and Saha (1996). Zini (1998) studied income convergence for Brazil using data from 1939-1994. The authors found evidence of unrestricted and restricted convergence for the period 1947-1994.

We now turn to a discussion of income convergence in Brazil using our extended data set. We estimated the restricted and unrestricted rates of convergence across Brazilian states using different econometric procedures. Llussa (2000) presents a revision of the econometric procedures on panel data estimation that have been used to estimate rates of convergence and discusses the associated problems. Table 3 presents the results. Ordinary Least Squares (OLS) mimics the procedure used in Barro (1991) and Mankiw, Romer and Weil (1992). The LSDV procedure reproduces panel data with fixed effects estimation as used in Islam (1995). The random effects procedure reproduces the estimation technique in Barro and Sala-i-Martin (1995) and GMM reproduces the procedure from Caselli, Esquivel and Leffort (1996). The problem with using OLS includes the omission of individual country effects, which result in an upward bias in the rate of convergence, and the endogeneity of the explanatory variables (including income per capita). On the other hand, the random effects assumption implies the correlation of the error term with the right-hand side variables due to the presence of initial income as lagged dependent variable.

Given that we do not have strict exogeneity but only predeterminacy of the explanatory variables we should not use LSDV with fixed effects or Minimum Distance estimation but GMM. The results obtained for the restricted and unrestricted rates of convergence are much higher relative to when we use OLS. Similar results are obtained by Caselli et al. (1996) in their study of a panel data set of countries. In other words, the unrestricted as well as restricted rates of convergence increase significantly.

Table 4 reports tests of specification for GMM, the only econometric procedure able to render consistent estimates. The Sargan test does not reject the validity of the overidentifying restriction. Also, we reject the null of no first-

order autocorrelation in the differenced residuals and we also reject the null of 
no second-order autocorrelation. The presence of first-order autocorrelation in the differenced residuals does not imply inconsistent estimates. However, the presence of second-order autocorrelation would imply inconsistent estimates and this may be a problem.

Our controls for the restricted model are the five regional dummies, North, Northeast, Southeast, South and Center-West. The reason we chose regional dummies as controls is that, within each region, states share geographical characteristics while across regions this is not true. Table 5 shows level regressions with different geographic characteristics as independent variables. When we use regional dummies as an independent variable, we obtain a high $R^{2}$ of 0.7478 which indicates that the geographic regions dummies are indeed relevant to explain per capita income dispersion. Indicators of climatic differences such as Dry and Wet Ecozones and Average Temperature and Area Subject to Floods are also important in explaining income differences. The fact that these geographic variables are, for the most part, time invariant, together with their high explanatory power, is indicative of the persistence of differences in income per capita among Brazilian states.

In terms of the standard deviation of the log of income per capita across Brazilian states we observe that the dispersion has remained basically the same from 1940 to 1995, as shown in Figure 1.

Figure 2 shows the dispersion of the log of income per capita within Brazilian regions. Now, we find evidence that disparity decreased over time for most regions, particularly the Southeast since 1940, the North since 1950 and the South region after 1965 . On the other hand, income dispersion increased slightly among states in the Northeast since 1940 and fluctuated substantially in the Center-West .

The geographic homogeneity among states within a region makes us think that geography could be important in the growth and convergence process. 


\section{Geography or Institutions: What Determines Income Levels?}

As noted above, the first Brazilian region to be settled was the Northeast, precisely the least developed today. A possible explanation is that the location in the tropics, tough beneficial at the time, created obstacles to long-term development. A large fraction of the Northeast's land area lies in the Tropical or Dry Ecozone and about $60 \%$ of its population reside in malaric areas. The Northeast is a rich region in terms of natural resources, which have so far been insufficiently explored given the associated high cost of exploration. Access to the sea is not a problem, given the region's extensive coastline. To evaluate the relative importance of geography and institutions in determining income levels across Brazilian states, we will compare estimates of two alternative models using instrumental variable estimation. Institutions will be instrumented with geographical characteristics to avoid reverse causality between growth and institutions, while different geographic characteristics will be added as additional controls.

Our Model I is given by:

$$
\begin{aligned}
\log y_{i t} & =\alpha_{0}+\alpha_{1} I N S T_{i t}+\varepsilon_{i t} \\
I N S T_{i t} & =\beta_{0}+\beta_{1} \operatorname{REGION}_{i}+\eta_{i t}
\end{aligned}
$$

and Model II by:

$$
\begin{aligned}
& \log y_{i t}=\delta_{0}+\delta_{1} I N S T_{i t}+G E O_{i t}^{\star} \delta^{\prime}+\xi_{i t} \\
& I N S T_{i t}=\beta_{0}+\beta_{1} \text { REGION }_{i}+\eta_{i t}
\end{aligned}
$$

where $y_{i t}$ is income per capita in state $i$ at time $t ; \hat{N S T}$ stands for the predicted value of each institution obtained in the first-stage regression of institutional indicators on region dummies. INST stands for each institution; REGION for the regional dummies. Model I instruments for institutions with the dummy variable indicating which region the state belongs to while Model II adds additional geographical determinants of long-run income levels. To check for robustness, two different sets of additional geographical controls are used in Model II, GEO1 and GEO2. While GEO1 stands for tropical ecozone, temperate ecozone, dry ecozone, wet ecozone, land area, coastal area, coastal population, temperature, humidity, rainfall and insolation; GEO2 includes only dry ecozone, wet ecozone, land area, coastal area, temperature, humidity and insolation. GEO2 is thus a subset of $G E O 1$ that excludes the geographical variables that tend not to be significant. These variables are described in the data appendix and, in some cases vary over time as well as across states.

Our results are shown in Tables $6 \mathrm{~A}$ to $6 \mathrm{D}$. For each variable, the first column presents the results instrumenting for institution (Model I) and the next two columns instrument for institution and, at the same time, add two additional sets of geographic control variables (Model II). For instance, in columns (1) to 
(3) of Table 6A, the variable Labor Force in Agriculture is the INST variable noted above.

While column (1) presents the estimate for $\hat{\alpha}_{1},{ }^{11}$ in column (2) we present an estimate of $\hat{\delta}_{1}$ with the GEO1 variables as controls; in column (3) we present a second estimate of $\hat{\delta}_{1}$ using the GEO2 subset of variables. As can be verified, variables that whereas Whites instrumented with regional dummies comes out as positive and significantly affecting income per capita, when other geographical variables are included Whites becomes insignificant. This pattern of significance of the coefficient on the instrumented institution that recedes into insignificance when geographical indicators area added is the main result in our exercise. It is common to Female Literacy (negative), ${ }^{12}$ Fertility (negative), Life Expectancy (positive), Infant Mortality (negative), Percent of Population Over 60 Years of Age (positive), Industrial GDP (positive), Neighbor (positive) and Centrality Measure (positive) ${ }^{13}$, and Political Competition (positive). The only institutional indicators whose effect remains significant after the extra geographical controls are added and that are not related to agriculture are Literacy and Political Alienation The lower the Percent of Alienation and the higher the Literacy Rate the higher the level of per capita income, whether we control or not for geography. The other institutional indicators that remain significant are related to agriculture: Labor Force in Agriculture (negative), Rural Population (negative) and GDP of Agriculture which may be explained by the structural transformation that is happening in the Brazilian economy during this period.

These results strongly suggest that, for the case of Brazil, geography dominates institutions in determining state income levels.

\section{Conclusion}

Substantial income differences between Brazilian states have persisted throughout the 20th century. Brazilian states display considerable variation in geographic and institutional characteristics in spite of sharing the same basic national institutions and no barriers to movement of labor and capital. This fact provides a singular testing ground for the relative importance of geography and institutions in determining levels of income per capita.

We find strong evidence of restricted and unrestricted convergence among Brazilian states, with the inclusion of regional dummies more than doubling the rate of convergence. This is consistent with a stable level of income per capita dispersion across all Brazilian states and decreasing dispersion of state income within regions. When we turn to the study of income differences, regional dummies seem to capture a substantial fraction of differences in geography and

\footnotetext{
${ }^{11}$ Here, as in all Tables, the heteroskedastic consistent standard error of the coefficient estimate is reported in parentheses.

${ }^{12}$ This is consistent with the result in Barro and Sala-i-Martin (1995), which finds a negative effect of female literacy on economic growth.

${ }^{13}$ Centrality Measure becomes negative but still significant in the second specification. However, in the third specification it is not significant anymore.
} 
institutions, explaining about 0.75 of total variation in the logarithm of state per capita income level. We then use regional dummies as instruments for institutions in income level equations. In virtually all of these specifications, institutions come out as significantly affecting income level, with the expected signs. However when other geographical characteristics are added as extra controls, institutions become insignificant. The exceptions are Literacy Rate, Political Alienation and some variables that are related to agriculture (Rural Population, Labor Force in Agriculture and GDP of Agriculture), whose effect on income levels is robust to geographic controls. A lower percentage of Political Alienation, Rural Pop, Labor Force in Agriculture, and GDP of Agriculture and higher literacy rate increase state income per capita. We conclude that geography matters most for growth. In Brazil, the relationship between institutions and income seems to be the result of the close association between institutions and geography. 
Figure 1

Standard Deviation of Log of Income

Among Brazilian States

(1950-1995)

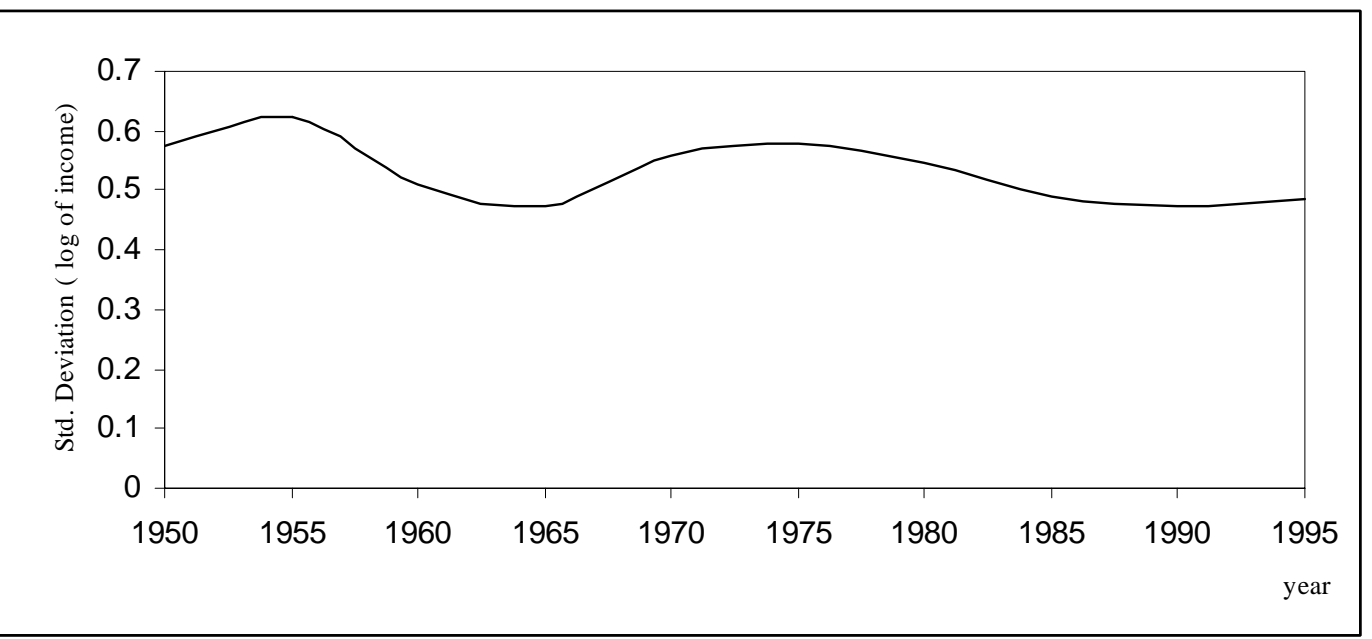

Figure 2

Standard Deviation of Log of Income

Among Brazilian States in Each Region

(1950-1995)

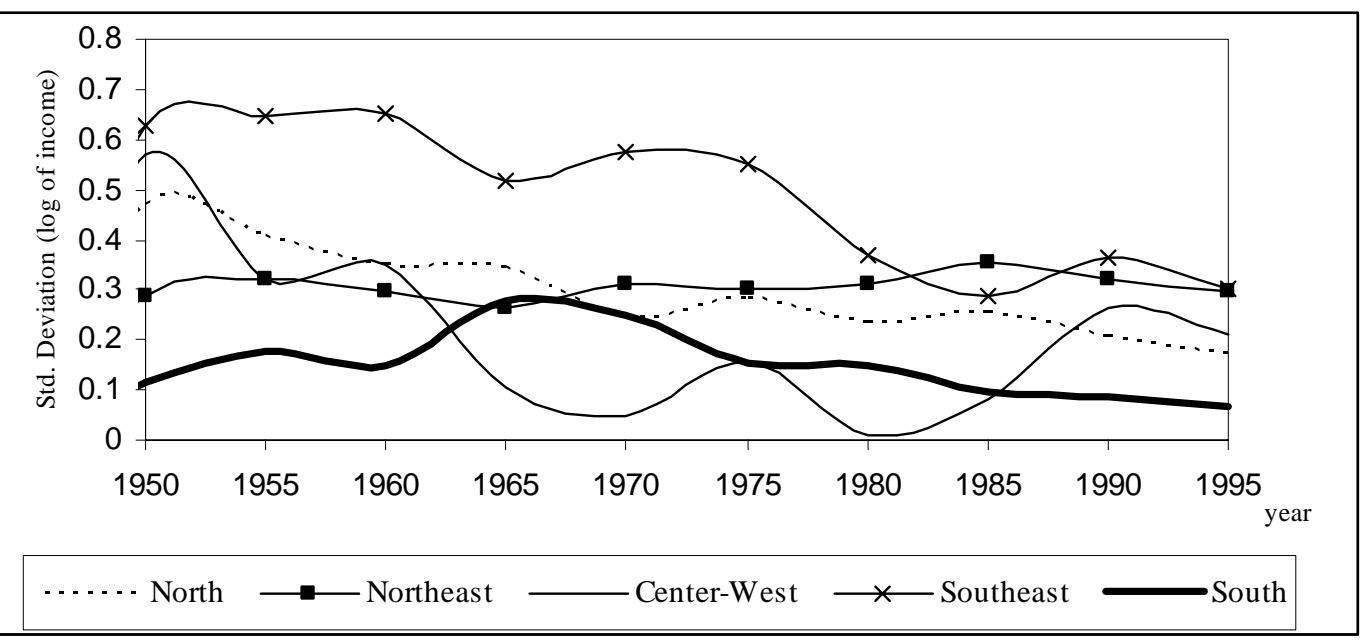


Table 1

Regional Geographic Characteristics

\begin{tabular}{l|c|c|c|c|c}
\hline & $\begin{array}{c}\text { North } \\
\mathbf{( 1 )}\end{array}$ & $\begin{array}{c}\text { Northeast } \\
\mathbf{( 2 )}\end{array}$ & $\begin{array}{c}\text { Center-West } \\
\mathbf{( 3 )}\end{array}$ & $\begin{array}{c}\text { Southeast } \\
\mathbf{( 4 )}\end{array}$ & $\begin{array}{c}\text { South } \\
\mathbf{( 5 )}\end{array}$ \\
\hline Land Area & 42.0 & 18.3 & 22.1 & 10.8 & 6.8 \\
Coastal Area & 6.9 & 19.7 & 0.0 & 14.8 & 20.3 \\
Coastal Population & 9.3 & 52.3 & 0.0 & 34.3 & 23.8 \\
Tropical Ecozone & 47.3 & 30.6 & 38.0 & 0.2 & 0.0 \\
Temperate Ecozone & 6.8 & 0 & 0 & 1.6 & 25.9 \\
Dry Ecozone & 14.7 & 61.8 & 40.8 & 0.8 & 1.2 \\
Wet Ecozone & 0.9 & 0.4 & 0 & 2 & 2.4 \\
Malaric Population* & 100 & 67 & 42 & 30 & 13 \\
Mineral Production * & 0.42 & 0.08 & 0.39 & 0.53 & 0.04 \\
Oil Production ** & 1.8 & 27.5 & 0.0 & 69.7 & 1.0 \\
\hline
\end{tabular}

Note: See data appendix for a full explanation of the variables. $\left({ }^{*}\right)$ Data refers to $1991 .\left({ }^{* *}\right)$ Data refers to 1995. 
Table 2

Regional Institutions

\begin{tabular}{|c|c|c|c|c|c|c|c|c|c|c|}
\hline & \multicolumn{2}{|c|}{ North } & \multicolumn{2}{|c|}{ Northeast } & \multicolumn{2}{|c|}{ Center-West } & \multicolumn{2}{|c|}{ Southeast } & \multicolumn{2}{|c|}{ South } \\
\hline & $\begin{array}{c}(1) \\
1940 \\
\end{array}$ & $\begin{array}{c}(2) \\
1995 \\
\end{array}$ & $\begin{array}{c}(3) \\
1940 \\
\end{array}$ & $\begin{array}{c}(4) \\
1995 \\
\end{array}$ & $\begin{array}{c}(5) \\
1940 \\
\end{array}$ & $\begin{array}{c}(6) \\
1995 \\
\end{array}$ & $\begin{array}{c}(7) \\
1940 \\
\end{array}$ & $\begin{array}{c}(8) \\
1995 \\
\end{array}$ & $\begin{array}{c}(9) \\
1940 \\
\end{array}$ & $\begin{array}{c}(10) \\
1995 \\
\end{array}$ \\
\hline Population & 3.6 & 6.7 & 35.0 & 28.8 & 3.0 & 7.2 & 44.5 & 42.5 & 13.9 & 14.8 \\
\hline Literacy* & 39.4 & 75.3 & 23.6 & 64.8 & 28.6 & 75.6 & 46.1 & 87.7 & 50.9 & 89.2 \\
\hline Female Literacy ** & 43.3 & 49.4 & 46.5 & 53.6 & 39.4 & 48.8 & 43.8 & 49.7 & 45.7 & 49.4 \\
\hline Agric. Labor Force & 25 & 12.5 & 37.6 & 42.6 & 34.7 & 25.6 & 28.7 & 14.4 & 33.7 & 30.3 \\
\hline Rural Population & 72.2 & 38.9 & 76.6 & 34.8 & 78.7 & 16.9 & 60.6 & 10.7 & 72.3 & 22.8 \\
\hline Life Expectancy* & 40.4 & 67.5 & 38.2 & 64.2 & 48.3 & 67.8 & 44.0 & 67.5 & 50 & 68.7 \\
\hline Infant Mortality & 168.4 & 53.2 & 178.7 & 88.2 & 134.8 & 33.0 & 152.8 & 30.0 & 127.4 & 26.7 \\
\hline Fertility** & 7.2 & 6.5 & 7.2 & 6.1 & 6.4 & 4.5 & 5.7 & 3.5 & 5.7 & 3.6 \\
\hline Older than 60 yrs. & 2.92 & 4.58 & 33.61 & 28.12 & 2.79 & 4.96 & 45.45 & 15.98 & 15.23 & 15.98 \\
\hline Whites** & 31 & 20 & 42 & 27 & 57 & 49 & 71 & 66 & 89 & 84 \\
\hline Political Competition & 1.31 & 1.85 & 1.79 & 1.30 & 0.46 & 1.96 & 2.36 & 2.59 & 1.76 & 1.69 \\
\hline Political Alienation & 0.33 & 0.57 & 0.21 & 0.56 & 0.23 & 0.51 & 0.18 & 0.50 & 0.18 & 0.48 \\
\hline GDPpc (USD) & 1134 & 2589 & 741 & 1910 & 1097 & 4425 & 2207 & 5451 & 1711 & 4723 \\
\hline GDP (Percent of total) & 2.0 & 4.3 & 16.7 & 13.6 & 2.1 & 7.9 & 63.2 & 57.0 & 15.3 & 17.3 \\
\hline Agric. GDP (\%) & 35.5 & 21.6 & 39.3 & 21.3 & 60.9 & 13.6 & 21.2 & 8.5 & 41.3 & 16.8 \\
\hline Ind. GDP (\%) & 16.7 & 34.6 & 13.6 & 27.9 & 8.8 & 19.7 & 21.4 & 35.0 & 15.8 & 36.0 \\
\hline Services GDP (\%) & 47.9 & 43.8 & 47 & 50.8 & 30.3 & 66.7 & 57.4 & 56.5 & 42.9 & 47.2 \\
\hline
\end{tabular}

Note: See data appendix for a full explanation of the variables. $\left(^{*}\right)$ Data in 1995 column refers to 1991. (**) Data in 1995 column refers to 1980. Data in percentage points

with the exception of Life Expectancy (in years), Infant Mortality (in 1,000 babies born), Fertility, Political Competiton and Political Alienation. 
Table 3

Dependent Variable: Five-Year Per Capita Growth Rates Unconditional and Conditional Convergence Rates (1950-95)

\begin{tabular}{|c|c|c|c|c|}
\hline & $\begin{array}{c}\text { OLS } \\
(1)\end{array}$ & $\begin{array}{c}\text { LSDV } \\
\text { (2) }\end{array}$ & $\begin{array}{l}\text { RE } \\
(3)\end{array}$ & $\begin{array}{c}\text { GMM } \\
(4)\end{array}$ \\
\hline$\lambda$ unrestricted & 0.016 & 0.092 & 0.015 & 0.214 \\
\hline s.e. & 0.004 & 0.013 & 0.005 & 0.091 \\
\hline$\lambda$ restricted & 0.048 & - & 0.038 & 0.280 \\
\hline s.e. & 0.007 & - & 0.007 & 0.088 \\
\hline $\mathrm{N}^{0}$ of States & 24 & 24 & 24 & 24 \\
\hline$N^{0}$ of Obs. & 216 & 216 & 216 & 216 \\
\hline
\end{tabular}

Note: All equations include year dummies. Ols with heteroskedastic-consistent standard errors; For the restricted rate of convergence, each equation includes regional dummies: north, northeast, south, southeast and center-west.

Table 4

\section{Dependent Variable: Five-Year Per Capita Growth Rates Unconditional and Conditional Convergence Rates (1950-95) Test Statistics}

\begin{tabular}{l|c|c}
\hline & $\lambda$ unrestricted & $\lambda$ restricted \\
\hline Sargan & 89.01 & 93.71 \\
p-value & 0.00 & 0.00 \\
Residual autocorrelation* & -6.93 & -6.46 \\
p-value & 0.00 & 0.00 \\
$\mathbf{m}_{\mathbf{2}}^{* *}$ & 1.69 & 1.38 \\
$\mathbf{p}$-value & 0.09 & 0.17 \\
$\mathbf{N}^{\mathbf{0}}$ of States & 24 & 24 \\
$\mathbf{N}^{\mathbf{0}}$ of Obs. & 192 & 192 \\
\hline
\end{tabular}

Note: All equations include year dummies. For the restricted rate of convergence, each equation includes regional dummies: north, northeast, south, southeast and center-west.

$\left(^{*}\right)$ Arellano-Bond test that average autocovariance in residuals of order one is zero.

(**) Arellano-Bond test that average autocovariance in residuals of order two is zero. 
Table 5

Dependent Variable: log of Income Per Capita

\begin{tabular}{|c|c|c|c|c|}
\hline & (1) & (2) & (3) & (4) \\
\hline North & $\begin{array}{c}-0.4702 \\
(0.051)\end{array}$ & & & \\
\hline Northeast & $\begin{array}{c}-0.9762 \\
(0.045)\end{array}$ & & & \\
\hline Center-West & $\begin{array}{c}-0.3198 \\
(0.065)\end{array}$ & & & \\
\hline Southeast & $\begin{array}{l}0.0847 \\
(0.079)\end{array}$ & & & \\
\hline Temperate Ecozone & & $\begin{array}{l}0.6473 \\
(0.167)\end{array}$ & & \\
\hline Tropical Ecozone & & $\begin{array}{c}-0.5628 \\
(0.140)\end{array}$ & & \\
\hline Dry Ecozone & & & $\begin{array}{c}-0.6916 \\
(0.070)\end{array}$ & \\
\hline Wet Ecozone & & & $\begin{array}{l}2.8681 \\
(0.904)\end{array}$ & \\
\hline Temperature & & & & $\begin{array}{l}-0.1117 \\
(0.009)\end{array}$ \\
\hline Humidity & & & & $\begin{array}{c}-0.0028 \\
(0.005)\end{array}$ \\
\hline Rainfall & & & & $\begin{array}{c}0.00004 \\
(0.00003)\end{array}$ \\
\hline Insolation & & & & $\begin{array}{c}-0.0001 \\
(0.00008)\end{array}$ \\
\hline Flood & & & & $\begin{array}{c}1.3696 \\
(0.2694)\end{array}$ \\
\hline $\mathbf{R}^{2}$ & 0.7478 & 0.3931 & 0.5465 & 0.7362 \\
\hline $\mathrm{N}^{0}$ of states & 24 & 24 & 24 & 24 \\
\hline$N^{0}$ of obs. & 240 & 240 & 240 & 200 \\
\hline
\end{tabular}

Note: heteroskedastic-consistent standard errors; All equations include year dummies. 
Table 6A

Dependent Variable: Log of Income per capita Instrumental Variable Estimation

\begin{tabular}{|c|c|c|c|c|c|c|c|c|c|c|c|c|}
\hline & (1) & (2) & (3) & (4) & (5) & (6) & (7) & (8) & (9) & (10) & (11) & (12) \\
\hline Agr. Labor Force & & & & $\begin{array}{c}-6.808 \\
(0.784)\end{array}$ & $\begin{array}{l}-4.089 \\
(1.036)\end{array}$ & $\begin{array}{l}-2.924 \\
(0.875)\end{array}$ & & & & & & \\
\hline Rural Pop. & & & & & & & $\begin{array}{l}-4.373 \\
(0.324)\end{array}$ & $\begin{array}{l}-3.579 \\
(0.623)\end{array}$ & $\begin{array}{l}-2.990 \\
(0.977)\end{array}$ & & & \\
\hline Whites & & & & & & & & & & $\begin{array}{c}1.387 \\
(0.217)\end{array}$ & $\begin{array}{c}-0.447 \\
(0.754)\end{array}$ & $\begin{array}{c}0.226 \\
(0.399)\end{array}$ \\
\hline Geography I & No & Yes & No & No & Yes & No & No & Yes & No & No & Yes & No \\
\hline Geography II & No & No & Yes & No & No & Yes & No & No & Yes & No & No & Yes \\
\hline
\end{tabular}

Note: heteroskedastic-consistent t-statistics presented in parentheses. All equations include year dummies. Institutions instrumented with regional dummies: north, northeast, south, southeast and center-west. Each specification is also estimated with two sets of geographical variables in addition to the instrumented institution. The set Geography I is composed of tropical ecozone, temperate ecozone, dry ecozone, wet ecozone, land area, coastal area, coastal population, temperature, humidity, rainfall and insolation, and the set Geography II is composed of dry ecozone, wet ecozone, land area, coastal area, temperature, humidity and insolation. See data appendix for a full explanation of the variables. 
Table 6B

Dependent Variable: Log of Income per capita Instrumental Variable Estimation

\begin{tabular}{|c|c|c|c|c|c|c|c|c|c|c|c|c|}
\hline & (1) & (2) & (3) & (4) & (5) & (6) & (7) & (8) & (9) & (10) & (11) & (12) \\
\hline Literacy & $\begin{array}{c}3.562 \\
(0.175)\end{array}$ & $\begin{array}{c}3.320 \\
(0.598)\end{array}$ & $\begin{array}{c}1.674 \\
(0.459)\end{array}$ & & & & & & & & & \\
\hline Female Literacy & & & & $\begin{array}{c}-13.574 \\
(1.841)\end{array}$ & $\begin{array}{l}-2.597 \\
(1.563)\end{array}$ & $\begin{array}{l}-2.565 \\
(1.622)\end{array}$ & & & & & & \\
\hline Fertility & & & & & & & $\begin{array}{l}-0.337 \\
(0.036)\end{array}$ & $\begin{array}{l}-0.111 \\
(0.069)\end{array}$ & $\begin{array}{c}0.085 \\
(0.173)\end{array}$ & & & \\
\hline Life Expectancy & & & & & & & & & & $\begin{array}{c}0.064 \\
(0.006)\end{array}$ & $\begin{array}{c}0.004 \\
(0.008)\end{array}$ & $\begin{array}{c}0.014 \\
(0.007)\end{array}$ \\
\hline Geography I & No & Yes & No & No & Yes & No & No & Yes & No & No & Yes & No \\
\hline Geography II & No & No & Yes & No & No & Yes & No & No & Yes & No & No & Yes \\
\hline
\end{tabular}

Note: heteroskedastic-consistent t-statistics presented in parentheses. All equations include year dummies. Institutions instrumented with regional dummies: north, northeast, south, southeast and center-west. Each specification is also estimated with two sets of geographical variables in addition to the instrumented institution. The set Geography I is composed of tropical ecozone, temperate ecozone, dry ecozone, wet ecozone, land area, coastal area, coastal population, temperature, humidity, rainfall and insolation, and the set Geography II is composed of dry ecozone, wet ecozone, land area, coastal area, temperature, humidity and insolation. See data appendix for a full explanation of the variables. 
Table 6C

Dependent Variable: Log of Income per capita Instrumental Variable Estimation

\begin{tabular}{|c|c|c|c|c|c|c|c|c|c|c|c|c|}
\hline & (1) & (2) & (3) & (4) & (5) & (6) & (7) & (8) & (9) & (10) & (11) & $(12)$ \\
\hline Infant Mortality & $\begin{array}{l}-0.015 \\
(0.002)\end{array}$ & $\begin{array}{l}-0.003 \\
(0.002)\end{array}$ & $\begin{array}{c}-0.004 \\
(0.002)\end{array}$ & & & & & & & & & \\
\hline Older & & & & $\begin{array}{c}0.065 \\
(0.009)\end{array}$ & $\begin{array}{c}-0.012 \\
(0.013)\end{array}$ & $\begin{array}{c}-0.023 \\
(0.009)\end{array}$ & & & & & & \\
\hline Political Alienation & & & & & & & $\begin{array}{c}-12.591 \\
(2.272)\end{array}$ & $\begin{array}{c}-5.258 \\
(1.613)\end{array}$ & $\begin{array}{l}-1.981 \\
(0.606)\end{array}$ & & & \\
\hline Political Competition & & & & & & & & & & $\begin{array}{c}1.206 \\
(0.179)\end{array}$ & $\begin{array}{c}0.310 \\
(0.282)\end{array}$ & $\begin{array}{c}0.932 \\
(0.424)\end{array}$ \\
\hline Geography I & No & Yes & No & No & Yes & No & No & Yes & No & No & Yes & No \\
\hline Geography II & No & No & Yes & No & No & Yes & No & No & Yes & No & No & Yes \\
\hline
\end{tabular}

Note: heteroskedastic-consistent t-statistics presented in parentheses. All equations include year dummies. Institutions instrumented with regional dummies: north, northeast, south, southeast and center-west. Each specification is also estimated with two sets of geographical variables in addition to the instrumented institution. The set Geography I is composed of tropical ecozone, temperate ecozone, dry ecozone, wet ecozone, land area, coastal area, coastal population, temperature, humidity, rainfall and insolation, and the set Geography II is composed of dry ecozone, wet ecozone, land area, coastal area, temperature, humidity and insolation. See data appendix for a full explanation of the variables. 
Table 6D

Dependent Variable: Log of Income per capita Instrumental Variable Estimation

\begin{tabular}{|c|c|c|c|c|c|c|c|c|c|c|c|c|}
\hline & (1) & (2) & (3) & (4) & (5) & (6) & (7) & (8) & (9) & (10) & (11) & (12) \\
\hline Agric. GDP & $\begin{array}{c}0.002 \\
(0.0001)\end{array}$ & $\begin{array}{c}0.001 \\
(0.0003)\end{array}$ & $\begin{array}{c}0.0007 \\
(0.0002)\end{array}$ & & & & & & & & & \\
\hline Ind. GDP & & & & $\begin{array}{c}0.001 \\
(0.0001)\end{array}$ & $\begin{array}{l}-0.00004 \\
(0.0002)\end{array}$ & $\begin{array}{c}0.0001 \\
(0.0001)\end{array}$ & & & & & & \\
\hline Neighbor & & & & & & & $\begin{array}{l}2.70 e-11 \\
(2.9 e-12)\end{array}$ & $\begin{array}{r}-4.33 e-12 \\
(3.1 \mathrm{e}-12)\end{array}$ & $\begin{array}{l}-2.74 \mathrm{e}-12 \\
(2.2 \mathrm{e}-12)\end{array}$ & & & \\
\hline $\begin{array}{l}\text { Centrality } \\
\text { Measure }\end{array}$ & & & & & & & & & & $\begin{array}{l}2.34 \mathrm{e}-09 \\
(2.8 \mathrm{e}-10)\end{array}$ & $\begin{array}{l}-1.37 e-09 \\
(5.3 e-10)\end{array}$ & $\begin{array}{c}-5.47 e-10 \\
(3.7 e-10)\end{array}$ \\
\hline $\begin{array}{l}\text { Geography I } \\
\text { Geography II }\end{array}$ & $\begin{array}{l}\text { No } \\
\text { No }\end{array}$ & $\begin{array}{l}\text { Yes } \\
\text { No }\end{array}$ & $\begin{array}{l}\text { No } \\
\text { Yes }\end{array}$ & $\begin{array}{l}\text { No } \\
\text { No }\end{array}$ & $\begin{array}{l}\text { Yes } \\
\text { No }\end{array}$ & $\begin{array}{l}\text { No } \\
\text { Yes }\end{array}$ & $\begin{array}{l}\text { No } \\
\text { No }\end{array}$ & $\begin{array}{l}\text { Yes } \\
\text { No }\end{array}$ & $\begin{array}{l}\text { No } \\
\text { Yes }\end{array}$ & $\begin{array}{l}\text { No } \\
\text { No }\end{array}$ & $\begin{array}{l}\text { Yes } \\
\text { No }\end{array}$ & $\begin{array}{l}\text { No } \\
\text { Yes }\end{array}$ \\
\hline
\end{tabular}

Note: heteroskedastic-consistent t-statistics presented in parentheses. All equations include year dummies. Institutions instrumented with regional dummies: north, northeast, south, southeast and center-west. Each specification is also estimated with two sets of geographical variables in addition to the instrumented institution. The set Geography I is composed of tropical ecozone, temperate ecozone, dry ecozone, wet ecozone, land area, coastal area, coastal population, temperature, humidity, rainfall and insolation, and the set Geography II is composed of dry ecozone, wet ecozone, land area, coastal area, temperature, humidity and insolation. See data appendix for a full explanation of the variables. 


\section{Appendix}

Agric. GDP: real agricultural Gross Domestic Product. Unit: 1995 "Real" . Unit: 1995 "Real" per kilometer. In this year, the exchange rate was 1 "Real" $\simeq 1$ USD. Source: Llussa (2003).

Agric. Labor Force: labor force in agriculture. Unit: ratio of total population. Source: Llussa (2003).

Center-West: dummy variable for states in the center-west region. Unit: zero or one. Source: Llussa (2003).

Centrality Measure: sum of the product of other states GDP divided by the distance between the capitals. Unit: 1995 "Real" per kilometer. In this year, the exchange rate was 1 "Real" $\simeq 1$ USD. Source: Llussa (2003).

Coastal Area: state area within 100 kilometers of the coast as a share of total state area. Unit: ratio of state area. Source: Llussa (2003).

Coastal Population: state population living within 100 kilometers of the coast as a share of total state population. Unit: ratio of total state population. Source: Llussa (2003).

Dry Ecozone: state area verifying a set of characteristics as to temperature, humidity, rainfall, insolation, vegetation, among others, classified as dry. Unit: ratio of total state area. Source: Llussa (2003).

Female Literacy: female population that "knows how to read and to write". Unit: ratio of total female population. Source: Llussa (2003).

Fertility: state fertility rate. Unit: births per thousand population Source: Llussa (2003).

GDP: state real GDP. Definition: Gross Domestic Product. Unit: 1995 "Real" per kilometer. In this year, the exchange rate was 1 "Real" $\simeq 1$ USD. Source: Llussa (2003).

GDPpc: per capita state real Gross Domestic Product. Unit: 1995 "Real" per capita. In this year, the exchange rate was 1 "Real" $\simeq 1$ USD. Source: Llussa (2003).

Flood: flooded state area. Unit: ratio of total state area. Source: Llussa (2003).

Humidity: relative humidity measured in the capital of the state. Unit: millimeters. Source: Llussa (2003).

Ind. GDP: real industrial Gross Domestic Product. Unit: 1995 "Real" per kilometer. In this year, the exchange rate was 1 "Real" $\simeq 1$ USD. Source: Llussa (2003).

Infant Mortality: number of infant deaths with less than one year old in relation to the number of born alive in that year. Unit: ratio of per thousand of children born alive. Source: Llussa (2003).

Insolation: insolation measured in the capital of the state. Unit: millimeters. Source: Llussa (2003).

Land Area: state area. Unit: square kilometers. Source: Llussa (2003).

Life Expectancy: number of years that an infant born alive would expect to live in case he was subjected to a statistical mortality law. Unit: years. Source: Llussa (2003). 
Literacy: state population that "know how to read and write". Unit: ratio of total state population. Source: Llussa (2003).

Malaric Population: state population that live in areas with malaria incidence. Unit: ratio of total state population. Source: Llussa (2003).

Mineral Production: value of the most important minerals produced in each state. Unit: ratio of the value of mineral production to the state GDP. Source: Llussa (2003).

Neighbor: sum of other neighboring state GDP weighted by the share of the distance between their capitals. Unit: 1995 "Real" per kilometer. In this year, the exchange rate was 1 "Real" $\simeq 1$ USD. Source: Llussa (2003).

North: dummy variable for states in the center-west region. Unit: zero or one. Source: Llussa (2003).

Northeast: dummy variable for states in the center-west region. Unit: zero or one. Source: Llussa (2003).

Oil Production: state petroleum production. Unit: in thousand liters.

Older than 60 yrs.: population older than 60 years of age in the state. Unit: ratio of total state population. Source: Llussa (2003).

Political Alienation: alienation index in elections for the state's federal deputy chamber. Unit: ratio of the sum of blank votes, default votes and abstentions to total votes. Source: Llussa (2003).

Political Competition: competitiveness index (CI) in the election for the state's federal deputy chamber. Unit: a) no competitiveness: $\mathrm{CI}<0$ (sub competitiveness), $\mathrm{CI}=0$ (zero-competitiveness), $0<\mathrm{CI}<0.1$ (quasi-zero competitiveness) and $0.1<\mathrm{CI}<0.6$ (almost competitive); b) competitive: $0.6<\mathrm{CI}<1.0$ (low competitiveness) and CI $>1.0$ (high competitiveness). Source: Llussa (2003).

Population: state population. Unit: number of inhabitants. Source: Llussa (2003).

Rainfall: rainfall measured in the capital of the state. Unit: millimeters. Source: Llussa (2003).

Rural Population: rural population in the state. Unit: ratio of total state population. Source: Llussa (2003).

Services GDP: real service Gross Domestic Product. Unit: 1995 "Real" per kilometer. In this year, the exchange rate was 1 "Real" $\simeq 1$ USD. Source: Llussa (2003).

South: dummy variable for states in the center-west region. Unit: zero or one. Source: Llussa (2003).

Southeast: dummy variable for states in the center-west region. Unit: zero or one. Source: Llussa (2003).

Temperate Ecozone: state area verifying a set of characteristics as to temperature, humidity, rainfall, insolation, vegetation, among others, classified as temperate. Unit: ratio of total state area. Source: Llussa (2003).

Temperature: temperature measured in the capital of the state. Unit: degrees centigrade. Source: Llussa (2003).

Tropical Ecozone: state area verifying a set of characteristics as to temperature, humidity, rainfall, insolation, vegetation, among others, classified as tropical. Unit: ratio of total state area. Source: Llussa (2003). 
Wet Ecozone: state area verifying a set of characteristics as to temperature, humidity, rainfall, insolation, vegetation, among others, classified as wet. Unit: ratio of total state area. Source: Llussa (2003).

Whites: white population in the state. Unit: ratio of total state population. Source: Llussa (2003). 


\section{References}

[1] Acemoglu, D., S. Johnson and J. A. Robinson (2001), "Reversal of Fortune: Geography and Institutions in the Making of the Modern World Income Distribution", NBER Working Paper No. w8460.

[2] Acemoglu, D., S. Johnson and J. Robinson (2000), "The Colonial Origins of Comparative Development: An Empirical Investigation", NBER Working Paper No. w7771.

[3] Arellano, M., and S. Bond (1991), "Some Tests of Specification for Panel Data: Monte Carlo Evidence and an Application to Employment Equations". Review of Economic Studies 58, 277-297.

[4] Baer, W. (1989), "The Brazilian Economy: Growth and Development", 3rd edition, revised and augmented, Praeger.

[5] Bajpai, N., and J. D. Sachs (1996), "India's Economic Reforms: Some Lessons from East Asia.", Journal of International Trade and Economic Development, 6, 135-164.

[6] Barro, R. (1991), "Economic Growth in a Cross-section of Countries". Quarterly Journal of Economics 106, 407-443.

[7] Barro, R., and X. Sala-i-Martin (1995), "Economic Growth". New York: McGraw-Hill.

[8] Ben-David, D. (1993), "Equalizing exchange: trade liberalization and income convergence. Quarterly Journal of Economics", 108, 653-679.

[9] Brown, W. (1997), "Democracy and Race in Brazil, Britain and the United States". The Edwin Mellen Press, Ltd., USA.

[10] Caselli, F., G. Esquivel and F. Lefort (1996), "Reopening the Convergence Debate: A New Look at Cross-Country Growth Empirics", Journal of Economic Growth 1:363-389.

[11] Cashin, P. and R. Saha (1996), "Internal Migration, Centre-State Grants and Economic Growth in States of India," IMF Staff Paper, 43, 123-71.

[12] Diamond, J. (1997), "Guns, Germs and Steel: The Fates of Human Societies", Random House.

[13] Engerman, S., and K. Sokoloff (1997), "Factor Endowments, Institutions, and Differential Paths of Growth Among New World Economies: A View from Economic Historians of the United States," in Stephen Haber, ed. "How Latin America Fell Behind", Stanford University Press (Stanford $\mathrm{CA})$.

[14] Furtado, C. (1979), ."Formação Econômica do Brasil", Editora Nacional (São Paulo SP). 
[15] Islam, N. (1995), "Growth Empirics: A Panel Data Approach". Quarterly Journal of Economics 110, 1127-1170.

[16] Gallup, J., J. D. Sachs and A.Mellinger (1998), "Geography and Economic Development", International Science Review, Vol. 22, no. 2 (August 1999): $179-232$.

[17] Hall, R. and C. Jones (1999), "Why Do Some Countries Produce So Much More Output per Worker than Others?", Quarterly Journal of Economics, Vol. 114, pp. 83-116.

[18] Knight, M. , N. Loayza, and D. Villaneuva (1993), "Testing the Neoclassical Growth Model ". IMF Staff Papers, 40,512-541.

[19] Leff, N. (1972), "Economic Development and Regional Inequality: Origins of the Brazilian Case, Quarterly Journal of Economics 86, 243-262.

[20] Leff, N. , (1982), "Economic Development in Brazil", 1822-1913". Reprinted in Haber, Stephen. (editor) (1997) "How Latin America Fell Behind", Stanford University Press (Stanford CA).

[21] Loayza, N. (1994), "A Test of the International Convergence Hypothesis Using Panel Data". Policy Research Working Paper No.1333, The World Bank.

[22] Llussa, F. (2003), "Data Set for Brazilian States". Mimeo, University of California Los Angeles.

[23] Llussa, F. (2000), "Conditional Convergence: A Panel Data Approach".Mimeo, University of California Los Angeles.

[24] Mankiw, N.G.D. Romer and D. Weil (1992), "A Contribution to the Empirics of Economic Growth ".Quarterly Journal of Economics 107,407-437.

[25] McArthur, J.and J. D. Sachs (2001), "Institutions and Geography: Comment on Acemoglu, Johnson and Robinson (2000)", NBER Working Paper No. 8114.

[26] Rodrik, D., A. Subramanian, and F. Trebbi (2002), "Institutions Rule: The Primacy of Institutions over Geography and Integration in Economic Development", NBER Working Paper No. w9305.

[27] Roett, R. (1978), "Brazil: Politics in a Patrimonial Society", Praeger Publishers.

[28] Romer, D. (1996), Advanced Macroeconomics.New York: McGraw-Hill.

[29] Sachs, J. D. (2003), "Institutions Don't Rule: Direct Effects of Geography on Per Capita Income", NBER Working Paper No. w9490. 
[30] Sachs, J. D., T. Jian and A. Warner (1996), "Trends in Regional Inequality in China", China Economic Review.

[31] Sachs, J. D., and A. Warner (1996), "Natural Resource Abundance and Long-Term Growth," Leading Issues in Economic Development, Oxford University Press, 2000.

[32] Solow, Robert (1956),. "A Contribution to the Theory of Economic Growth". Quarterly Journal of Economics 70,65-94.

[33] Zini, A. A. (1998), "Regional Income Convergence in Brazil and its SocioEconomic Determinants", Economia Aplicada, v.2,nº 4, FEA/USP. 